\title{
LIQUIDITY MANAGEMENTAND PERFORMANCE OF DEPOSIT MONEY BANKS IN NIGERIA
}

\author{
Eze Emmanuel ${ }^{1}$ \\ ${ }^{1}$ Department of Accounting, \\ Rhema University, \\ Aba, \\ Nigeria \\ Agu Stephen ${ }^{2}$ \\ ${ }^{2}$ Department of Accounting, \\ Institute of Management and Technology, \\ Enugu, \\ Nigeria.
}

Article DOI: https://doi.org/10.36713/epra3138

\begin{abstract}
This study was carried out on liquidity management and performance of deposit money banks in Nigeria using six banks with international affiliation. In particular, the paper established the relationship between the variable of bank performance and those of liquidity management using capital adequacy, liquidity ratio, and current ratio as indicators and bank size as a control variable. Data were extracted from annual reports from the banks' websites for a period spanning seven years (2013 2019). Descriptive statistics and regression analysis were performed using the E-View 10.0 as instrument for the analysis. Findings indicate a strong positive relationship between capital adequacy and return on equity while liquidity and current ratio showed statistical insignificant negative relationship with return on equity. Bank size showed a strong positive relationship with return on equity. It was recommended that the regulatory body should ensure that deposit money banks in Nigeria are adequately capitalised to guarantee system stability while the bank managers should adhere to reserve requirements from the Central Bank so as to absorb financial shocks and operate profitably.
\end{abstract}

KEY WORDS: performance, liquidity, capital adequacy, current ratio,

\section{INTRODUCTION}

Financial intermediation is considered a major function of deposit money banks in Nigeria. By the execution of this function, funds are collected from the surplus units of the society which can be withdrawn on demand or channeled to the investment units who are in need of such fund. Thus, there is a gap of filling the demands of the depositors of the fund and lending to the deficit economic units and these must be matched in a manner that no financial shocks will be created in the system. In the opinion of scholars, such as
Otekunrin,Nwanji, Agba, Olowooker, Fakile, Lawal, Ajayi and Falaye (2018), a bank's capability of meeting customers' withdrawal needs and other cash flows is an indication of her liquidity management. Drawing from this statement and in accordance to Bhattacharyya and Sahoo (2011), liquidity management encompasses maintenance of enough cash balance and its equivalent balances to satisfy the needs of the customers at any point in time as well as ensuring that money is also available to execute the daily operations of the bank. In the process of performing these functions, the banks 
should be able to make profit for her major and other stakeholders who are very essential for its continued existence and operations. However, achieving profitability demands striking a balance between liquidity and how it is managed. Liquidity is analogous to the circulation of blood in the human system; lack of blood weakens the system but the system would be sound where the blood is at the optimum level. Consequent to this, Akinwumi, Essien and Adebgoyega (2017) alluded liquidity and profitability to two centrifugal forces operating at the opposite continuum which put the bank at a risky position. A trade-off should be maintained between inadequate liquidity and excess liquidity as each of these has profound effect on the banks performance in terms of profitability (Padache, 2006).

The importance of liquidity management cannot be overemphasized and this is the reason behind the Central Bank's various reforms which are intended to ensure system stability and the restoration of confidence in the Nigerian financial system. Much as profit is very essential for the going concern of banks, liquidity management remains a sine qua non for the attainment of profitability. This study was empirically conducted to examine the relationship between liquidity management and performance of deposit money banks and to determine the nature of relationship in existence with a focus on six of the banks with international affiliation, whose annual reports were available at the time of the study. Liquidity management as the independent variable consists of capital adequacy ratio, liquidity ratio, current ratio and bank size as control variable while performance is the dependent variable proxied by return on equity.

\subsection{Statement of problem}

Banks are established like any other businesses for profit making for the major and other stakeholders. The achievement of the profit depends on the financial health status of the banks which is primarily determined by the ability of the banks to hold sufficient liquid assets in the right proportion so that all regulatory requirements would be complied by while at the same time continuing the normal operations of paying their depositors on demand and making investment that will also shore up her profit objective. Much as lack of liquidity portends risks to the banks, excess liquidity is also at a peril to the banks. Risks are associated with losses or inability to generate profit with the negative attendant effect on the going concern status of the firms. It is therefore pertinent that deposit money banks should manage their liquidity in such a manner that a trade off would be struck between liquidity and investment such that sudden shocks that may bring the corporate life of the organizations to an end would be avoided. Liquidity management has been identified in this paper to be associated with the maintenance of capital adequacy ratio, liquidity ratio, cash ratio while log of total assets was introduce as a control variable.

Several studies have been carried out by scholars with mixed results; some hold that liquidity management and performance are positively related while others found negative association between liquidity management and performance. A good number of the works conducted in this area lacks currency. This study was therefore carried out to provide further verification on the relationship between liquidity management and performance of deposit money banks in Nigeria.

\subsection{Objective of the study}

The major objective of this study is to investigate the relationship between liquidity management and performance of deposit money banks in Nigeria between 2013 and 2019. In particular, the study was intended to:

(i) Examine the relationship between liquidity management and performance of deposit money banks

(ii) Establish the relationship between capital adequacy and performance of deposit money banks.

(iii) Establish the relationship between cash ratio and performance of deposit money banks.

\subsection{Research Hypotheses}

The following testable propositions are stated in the null form:

$\mathrm{Ho}_{1:}$ There is no significant relationship between liquidity management and performance of deposit money banks.

$\mathrm{Ho}_{2}$ : There is no significant relationship between capital adequacy and performance of deposit money banks.

$\mathrm{Ho}_{3}$ : There is no significant relationship between cash ratio and performance of deposit money banks.

\subsection{REVIEW OF RELATED LITERATURE \\ 2.1 Concept of Liquidity and Liquidity Management}

The academic hall is replete with avalanche of perceptions from researchers on the subject matter of liquidity. It is pertinent to state that there is no universally acceptable concept of liquidity because of the eclectic nature of the concept which results from various economic viewpoints (Ibe, 2012). However, the meaning of liquidity revolves around marketability of security and funding ability of banks (Basel Committee 
on Banking Supervision, 2008). This understanding was shared by Marozva (2015) and Shafique, Faheem and Abdullah, (2012) who defined marketability of security from the purview of the ease of trading such instrument while funding ability is the easiness of converting security to cash. This view was corroborated by Olagunju, Adeyanju and Olabode (2011), conceiving liquidity as the ability of a concern to meet its short term obligations or the conversion of its assets into cash. Scholars such as Amengor's (2010) and Alshatti (2015) strongly advocate that liquidity is the ability of banks to meet the financial needs of their increased assets and meeting liabilities as and when they fall due without the incidence of unexpected losses. Different scholars use different financial ratios to measure liquidity such as Ilhomovich (2009), who employed cash to deposit ratio but this work used loans and advances to total assets.

Drawing from the above, it can be gleaned that the scopes of liquidity is based on the timing required in converting assets of banks into monetary asset or cash. Koranteng (2016) attributes a bank's liquidity to its ability to acquire cash through deposits and finally, its ability to reinvest as and when needed. In the opinion of Bhunia and Khan (2011), profitability of deposit money banks is tied to efficient management of liquidity and Olatunde (2015), observed that the improvement and maintenance of liquidity coverage ratio by the regulators is in tandem with increase in business growth and performance. The significance of liquidity demands that the regulators should ensure compliance while management of the banks should observe to comply with the maintenance of minimum liquidity requirement and invest available resources in profitable window. Among the ratios used as proxy for liquidity management in this study is capital ratio which indicates the effectiveness and soundness of the system. Moreover, researchers like Devinaga and Tan (2010), as well as Vong (2005) have observed that capital ratio is instrumental to profitability and performance of deposit money banks. Cash ratio is another variable used for liquidity management in this work and is of interest to creditors who are attracted by the ability of a concern to settle her maturing obligations as at when due and maintains a level of cash to take advantage of other investment activities. However, the level of cash should be maintained through appropriate trade-off so that profit should be generated by investing any excess cash to earn returns and identify when the cash level is low so as not to experience financial shock that may lead to losses.

\subsection{Theoretical Review}

Extant literature on liquidity and performance of deposit money banks are inundated with several theories but the ones that underpin this study are but not limited to Liquidity-Profitability trade-off theory and Self-Liquidating Paper Theory as briefly discussed below.

\subsubsection{Liquidity-Profitability trade-off theory}

The emphasis of this theory is the synchronization of liquidity and maturity which ensures that a mismatch capable of causing financial shock and runs in the bank does not occur. The theory maintains that a bank can be vulnerable if a skewed relationship occurs between the two. Regulatory authorities are mindful of the importance of safety and soundness in the system thereby setting required maintainable ratios that position banks to easily discharge their liabilities without compromising investible funds that would yield returns. Researchers agree that liquidity is as important as capital to the banks for the maintenance of stability. Bagyenda, Brownbridge and Kasekende (2011) concluded from their study that banks with high liquidity and superior capital are not likely to experience failure at a time of financial crisis. This theory is adopted from the work of Akinwumi et al (2017) primarily for taking into consideration, the financial performance of banks and liquidity cash ratio variable which measures the short term liquidity positions of banks as modeled in this paper.

\subsubsection{Self-Liquidating Paper Theory}

This theory, referred to as the Commercial Loan theory discourages banks from extending long term lending. In other words, these are the most liquid loan the banks can give and is widely accepted as a means of sustaining liquidity of banks. Drawing from the view of Leonard (2011), the theory anchors on the short term loan or lending which the bank extends to finance saleable goods from the producer to the consumer. The loans are self-liquidating in the sense that products are produced and evolved through transportation, manufacturing, storage and distribution channels (Ibe, 2013). Self-liquidating loan ensures that short-term profit motive should be matched with short-term obligations by making depositors' funds available when needed. Onoh (2002) points out that for liquidity management to be effective in this direction, the tenor of funds from depositors and other sources must be matched with that of assets ( loans and advances). Selfliquidating loan is a source of current working capital to firms and originates from trade transactions secured by physical goods, repayable out of the price obtained by their sales (Shekhar \& Shekhar, 2005; Gomez, 2008). However, the side effect attributed to this theory 
by Gomez (2008), is that it reduces the purchasing power of borrowers which is evident during depression period when traders or borrowers experience trade hiccups, resulting to losses and delay in meeting up with bills on maturity.

\subsection{Review of Empirical Studies}

The aim of this review is to investigate published works, periodicals and books that discuss theory and observed results relevant to the topic at hand (Zikmund, Babin, Carr \& Griffin, 2010).

Bassey and Moses (2015) carried out a study on the relationship between bank performance and liquidity management using a target population of fifteen banks. The secondary data for the study were obtained from published reports and the ordinary least square method was employed in analyzing the data. Findings revealed an adverse correlation between liquid money ratio and equity returns whereas an ideal positive correlation existed among loans, asset ratio, loans and equity returns. They recommended that banks should not only centre on the focal point of profit maximization but maintain a balance of customer satisfaction through the application of liquidity management approaches.

Another country specific study was conducted by Daniel (2017), who surveyed management of liquidity and its impact on the efficiency of banks. This was based on a study period of 25 years (1986-2011) with a target population of 24 banks. Data for the research were obtained from secondary sources and analyzed using the SPSS package. The results of this study indicated that liquidity management positively influences the operations of deposit money banks. The researcher also explained the data using correlation analysis and found that equity returns and cash liquidity reserve ratio are positively related, while equity returns and deposit loan ratio are negatively related. He further recommends that banks should adopt optimum liquidity strategies

for the smooth running of the business. Other scholars whose works resulted to a positive significant relationship between liquidity and profitability of deposit money banks were Khan and Ali (2016); Abubakar (2015); Osuji (2013); Olagunju, David, and Samuel, (2012) and Kosmidou, (2008). However, some researchers conducted studies on the same subject matter but reported a negative significant relationship between liquidity and profitability of deposit money banks (Marozva,2015; Raheman \& Nasr, 2007) while other studies reported no significant impact of liquidity on profitability of deposit money banks (Abdullah \& Johan, 2014; Lartey, Antwi, \& Boadi, 2013; Shen, Docquier, \& Rapoport, 2010).
Naceur and Kandil (2009) carried out investigate on the effects of capital regulations on cost of intermediation and profitability in Egyptian commercial banks. Findings revealed that higher capital adequacy increases the interest of shareholders in managing banks' portfolios and other factors such as higher capital requirements, reduction in indirect cost, and enhanced management efficiency have contributed positively to banks' profitability in the post-regulation period while the reduction in economic activity has side effects on profitability.

Larty et al (2013) conducted a study to find out the existing relationship between liquidity and profitability among banks quoted in Ghanaian Stock Exchange for the period 2005 - 2010. The study employed panel data from secondary sources and made use of descriptive statistics and regression analysis. Findings showed a very weak relationship between liquidity and profitability.

Ogonna and Ikechukwu (2016) assessed the effects of liquidity management on the performance of deposit money banks in Nigeria covering sixteen years $(2000-2015)$. Data for the study were gathered from the CBN and NDIC annual publications for the stated period. Using the regression statistical analysis with the aid of E-View 8.0, the result revealed a negative and significant relationship between liquidity and profitability of deposit money banks in Nigeria. Also, a positive and significant relationship was identified between cash to deposit ratio and profitability.

Charlmer et al (2018), examined the level of bank liquidity, the trend of bank liquidity and the impact on the profitability of commercial banks in Ghana. The study involved twenty one banks for a period of ten years (2007-2016). Secondary data in form of a panel were analysed employing descriptive statistics, correlation and regression analysis. The results showed a positive relationship between returns on assets and liquidity but a weak positive relationship between returns on equity and liquidity. However, a negative relationship was observed between return on equity and liquid assets to total interest bearing liabilities while bank size, capital adequacy among others showed a positive association.

In Kenya, Sile, Olweny and Sakwa (2019) carried out a study on liquidity as a determinant of banks financial performance using all the forty three commercial banks for the study period (2012-2016). The study made use of secondary data collected from audited financial statements of the banks. Descriptive statistics and regression analysis employed showed a negative relationship between financial performance and liquidity management. 


\subsection{RESEARCH METHODOLOGY}

This desk study adopted the descriptive research design in line with Bassey and Moses (2015) and Ramadan, Kilani, and Kaddumi (2011) as contained in Otekunrin , Fagboro, Nwanji, Asamu, Ajiboye and Falaye (2019). The sample size of the research work was six out of eight deposit money banks with international affiliation and the period was 2013 2019 , constituting a forty two firm year. The choice of the banks and the study period was based on the availability of current annual reports from the banks' website as at the time of the study. The simple random technique was adopted in the selection of the sample because every element stands the chance of being selected in the survey exercise. This further reduces prejudice and facilitates the analysis of the results. The analysis carried out to determine the type of relationship existing between liquidity management and performance of deposit money banks in Nigeria with international affiliation employed the ordinary least square technique.

\subsection{Empirical Model Estimation \\ 3.1.1 Dependent Variable}

In this study, performance is employed as the dependent variable of the model. There are various measures of performance each of which revolves around profitability. However, profitability could be in terms of prior or post tax. Previous studies used measures of profitability such as return on asset, return on equity, firm margin etc., (Charmler, Musah, Akomeah \& Gakpetor, 2018). This study adopted return on equity as a proxy for performance.

\subsubsection{Independent Variables}

Liquidity management is measured by three variables in this work: capital adequacy which is expressed as total equity to total assets in percentage; Liquidity ratio, measured as loans and advances to total assets and current ratio, measured as the ratio of cash and cash equivalent to current liabilities.

\subsubsection{Control Variable}

The control variable for the study is size which is described as one of the major determinants of bank profitability (Musah, 2017; Musah, Anokye, \& Gakpetor, 2018). Studies have shown that profitability is relative to the size of banks which implies that bigger banks are more profitable because they have more financial clout to invest in bigger projects to earn higher returns. Notwithstanding, previous works have equally revealed that smaller banks are expected to be more technologically inventive and profit driven. Size is measured by the natural logarithm of total assets which applies to the deposit money banks used in this study.

\subsection{Model Specification}

This paper adopted the regression method for panel study employed by Kuznetsov and Muravyev (2001) with the general form given as Yit $=\alpha+\beta$ Xit + eit

Where: $\mathrm{i}=$ the individual cross-sectional dimension (i.e. Banks), and $\mathrm{t}=$ the time dimension (i.e. 20132019);

$\alpha=$ constant/intercept; $\beta=$ the coefficients;

Yit $=$ dependent variables/Profitability measure (which is a measure of return on equity);

$\mathrm{Xit}=$ the independent variables of the model (capital adequacy, liquidity ratio, current ratio and size as control variable); eit $=$ the residual error of bank $\mathrm{i}$ at time, $\mathrm{t}$.

$$
\begin{aligned}
& \text { ROEit }=\beta 0+\beta 1 \text { CADQ1 it }+\beta 2 \text { LIQDT2 it }+\beta 3 \text { CRit } \\
& +\beta 4 \text { SIZEit }+\varepsilon \text { it }
\end{aligned}
$$

\subsection{Variable Definition and Measurement}

\begin{tabular}{|l|l|l|}
\hline \multicolumn{1}{|c|}{ Variable } & Acronym & \multicolumn{1}{c|}{ Measurement } \\
\hline Return on Equity & ROE & Profit before tax divided by total equity. \\
\hline Capital Adequacy & CADQ & Total Equity divided by Total Assets \\
\hline Liquidity & LIQDTR & Loans and Advances divided by Total Assets \\
\hline Current Ratio & CR & Cash and Cash Equivalents divided by Current Liability \\
\hline Bank Size & SIZE & Natural Logarithm of Total Assets. \\
\hline
\end{tabular}




\subsection{PRESENTATION AND INTERPRETATION OF DATA}

\begin{tabular}{lccccc}
\multicolumn{7}{c}{ Table 4.1: Descriptive Statistics } \\
Mean & ROE & CADQ & LIQDT & CR & SIZE \\
Median & 18.89829 & 13.72268 & 0.498859 & 0.356388 & 6.400785 \\
Maximum & 19.88000 & 14.19000 & 0.469400 & 0.347800 & 6.422000 \\
Minimum & 37.41000 & 18.48000 & 0.945100 & 0.785300 & 6.854100 \\
Std. Dev. & 4.780000 & 8.540000 & 0.306100 & 0.145400 & 6.003600 \\
Skewness & 8.309932 & 2.403716 & 0.144411 & 0.155894 & 0.244300 \\
Kurtosis & 0.223553 & -0.274491 & 1.522348 & 0.511346 & -0.035053 \\
& 2.448496 & 2.661724 & 4.882522 & 2.636384 & 1.872366 \\
Jarque-Bera & 0.861104 & 0.710346 & 21.89069 & 2.012616 & 2.180643 \\
Probability & 0.650150 & 0.701052 & 0.000018 & 0.365566 & 0.336108 \\
& & & & & \\
Sum & 774.8300 & 562.6300 & 20.45320 & 14.61190 & 262.4322 \\
Sum Sq. Dev. & 2762.199 & 231.1140 & 0.834183 & 0.972113 & 2.387307 \\
& & & & & \\
Observations & 41 & 41 & 41 & 41 & 41
\end{tabular}

Source: Researcher's EView 10.0 Output.

The summary of the statistical properties of the variables used in this empirical study as shown above in table 4.1 presented the average value of the Return on Equity (ROE), a performance proxy of the selected Nigerian banks as $189 \%$ approximately (18.89829), this implies sample selected banks on average earned a net income of $189 \%$ of total asset with a maximum and minimum value of 37.41000 and 4.780000. The standard deviation is 8.309932 .

On the other hand, the average value of the sampled banks 'liquidity management is 137 percent (13.72268) which was measured by Capital Adequacy (CADQ), this reflects that these banks operate with 137 percent level of total equity to total asset and the maximum and minimum value of 18.48000 and 8.540000 respectively. It deviates by 2.403716 from the mean value of the sampled selected Nigerian banks.

The liquidity management of the sample banks has on average $50 \%$ appropriately (mean $=0.498859$ ) as measured by Liquidity ratio (LIQDT). The maximum value of Liquidity ratio among the sample banks is 0.945100 and the minimum value is 0.306100 .It shows a standard deviation of 0.144411 from the mean value.

Again, the liquidity management of the sample banks surrogated by current ratio (CR) has on average $36 \%$ appropriately $(0.356388)$ with a maximum and minimum value of 0.785300 and 0.145400 . The standard deviation is 0.155894 .

Finally, a supporting variable, bank size has on average up to $640 \%$ (i.e., 6.400785 ) of the sampled banks with the maximum and minimum value of 6.854100 and 6.003600 respectively. It deviates by 0.244300 from the mean value of the sample of selected Nigerian banks.

In this case, Skewness coefficient shows that all the variables under study have values less than 1 and this indicates that their frequency distribution is normal. Kurtosis coefficient support the result of Skewness as it relates to return on equity (ROE), Capital Adequacy (CADQ), current ratio (CR) and bank size (SIZE) as their coefficient is less than 3, except for Liquidity ratio (LIQDT) which has value greater than 3 indicate that they are not normally' distributed. Jarque - Bera statistic show that the return on equity (ROE), Capital Adequacy (CADQ), current ratio (CR) and bank size (SIZE) have p-value greater than 0.05 which show that they are not significant and it implies that they are normally distributed supporting the result of Kurtosis. 
Table 4.2: Panel Least Squares

Dependent Variable: ROE

Method: Panel Least Squares

Date: $07 / 13 / 20$ Time: 04:42

Sample: 20132019

Periods included: 7

Cross-sections included: 6

Total panel (unbalanced) observations: 41

\begin{tabular}{crlll}
\hline \hline \multicolumn{1}{c}{ Variable } & Coefficient & Std. Error & t-Statistic & Prob. \\
\hline \hline CADQ & 1.502700 & 0.394738 & 3.806830 & 0.0005 \\
LIQDT & -4.673370 & 6.358688 & -0.734958 & 0.4671 \\
CR & -5.140108 & 5.854585 & -0.877963 & 0.3858 \\
SIZE & 26.33957 & 3.695169 & 7.128111 & 0.0000 \\
C & -166.1535 & 24.67346 & -6.734100 & 0.0000 \\
\hline \hline R-squared & 0.621518 & Mean dependent var & 18.89829 \\
Adjusted R-squared & 0.579464 & S.D. dependent var & 8.309932 \\
S.E. of regression & 5.388886 & Akaike info criterion & 6.320404 \\
Sum squared resid & 1045.443 & Schwarz criterion & 6.529376 \\
Log likelihood & -124.5683 & Hannan-Quinn criter. & 6.396500 \\
F-statistic & 14.77919 & Durbin-Watson stat & 0.982797 \\
Prob(F-statistic) & 0.000000 & & & \\
\hline \hline
\end{tabular}

Source: Researcher's EView 10.0 Output

From the regression analysis, Table 4.2 indicates that there is a positive (t-statistics, 3.806830) and significant ( $\mathrm{p}$-value, 0.0005) association between Capital Adequacy (CADQ) and Return on Equity (ROE) of the sampled banks. This positive effect implies that a $1 \%$ increase in Capital Adequacy (CADQ) will tend to increase the level of Return on Equity (ROE) by 1.502700 .By this, Capital Adequacy (CADQ) has positive significant effect on the Return on Equity (ROE) of the selected banks. The same table above also showed that the supporting variable, Bank size has a positive significant effect on the Return on Equity (ROE) of the selected banks with t-statistics of 7.128111 and $p$-value of 0.0000 .This implies a $1 \%$ increase in the Size of the banks will tend to increase the level of Return on Equity (ROE) by 26.33957.

In contrary, Liquidity of the banks has a negative (t-statistics, -0.734958) and insignificant (pvalue, 0.4671) effect on Return on Equity (ROE) of the sampled banks. This negative effect implies that a $1 \%$ increase in Liquidity (LIQDT) will tend to decrease the level of Return on Equity (ROE) by -4.673370.This is in consonance with Marozva (2015) research report. In same vein, Current ratio (CR) resulted to a negative (tstatistics, -0.877963) and insignificant ( $p$-value, 0.3858) effect on Return on Equity (ROE) of the sampled Nigerian banks. The negative effect indicates an inverse relationship between current ratio and Return on Equity (ROE) of the selected banks.

$\mathrm{R}^{2}$ measures the percentage of Return on Equity that could be explained by changes in independent variables, Capital Adequacy (CADQ), Liquidity (LIQDT), Bank size (SIZE) and Current ratio (CR).Here, $\mathrm{R}^{2}$ adjusted is 0.579464 (58\%) which implies that $58 \%$ of variation in return on equity could be explained by the effect of independent variables while about $42 \%$ could be attributed to other factors capable of effecting changes in return on equity of Nigerian banks. Here also, the Durbin-Watson statistic is 0.982797. This indicates the absence of autocorrelation in the data series.

\subsection{FINDINGS, CONCLUSION AND RECOMMENDATIONS}

\subsection{Findings}

The following findings were made concerning the interplay between Liquidity Management and Performance of Deposit Money Banks in Nigeria.

a. There is statistical positive and significant relationship between Capital Adequacy (CADQ) and Return on Equity (ROE) of the Deposit Money Banks in Nigeria. 
b. There is statistical negative and insignificant relationship between Liquidity (LIQDT) and Return on Equity of the Deposit Money Banks in Nigeria.

c. Current ratio (CR) has statistical insignificant negative correlation with Return on Equity of the Deposit Money Banks in Nigeria.

d. There is statistical positive and significant relationship between Bank size (SIZE) and Return on Equity (ROE) of the Deposit Money Banks in Nigeria.

\subsection{Conclusion}

Referring to the analysis and findings as shown above, profitability and capital adequacy of deposit money banks in Nigeria have a positive relationship. This entails that an increase in capital leads to an increase in profitability of the banks and vice versa. This finding agrees with the works of scholars such as Kosmidou (2008); and Molyneux (1993) in Charmler et al (2018). Naceur and Kandil (2009) in their opinion concluded that banks with higher level of equity operate at reduced cost of capital and can as well invest part of their capital in the interbank market and other investment window to increase profitability. Besides, deposit money banks with strong capital base have the clout and capacity to absorb financial shocks and invest in portfolios considered risky but with higher returns which shore up profitability.

Size as a control variable in the model showed a significant and positive relationship with return on equity, the performance proxy. This aligns with the findings of Amidu (2007) and Musah (2017), an indication that larger banks operate at economies of scale and diversification status which tend to increase profitability with favourable influence on risk and product portfolio.

The p-value of the F-statistics at 5\% level explains that the null hypothesis should be rejected and that the independent variables significantly link with the dependent variable.

The study result showed a negative relationship between liquidity and return on equity. This means that as liquidity increases, the return on equity decreases. This agrees with (Marozva,2015; Raheman \& Nasr, 2007; Liu et al (2010); Ogonna \& Ikechukwu (2016).

However, findings from scholars like Rachi (2013), Larty et al (2013), Sile et al (2019) and Daniel (2017) revealed a positive relationship, thus an interplay exists between excess liquidity and profitability on the opposite continuum. It requires that banks should maintain a balance between the two because excessive liquidity stifles profitability as excessive profitability is vulnerable to banks' insolvency (Flannery \& Rangan, 2008).
Further finding from the analysis revealed an existence of a negative and insignificant effect between return on equity and current ratio. The result indicates that returns on equity has a negative association with current ratio, an affirmation that excess cash do not significantly determine returns on assets or equity. The result however, conflicts with the finding in the study carried out by Otekunrin et al (2019). The p-value of the F-statistics at 5\% level explains that the null hypotheses should be accepted and that the independent variables insignificantly link with the dependent variable

Also, the Durbin-Watson result shows the absence of autocorrelation in the data series and confirms the statistical reliability of the model which shows that there is a significant relationship between return on equity as a proxy for performance and liquidity management.

\subsection{Recommendations}

Flowing from the conclusion, liquidity management proxied by capital adequacy, liquidity ratio, current ratio and bank size as a control variable are related with performance proxied by return on equity. On the strength of the above outcome, the following recommendations are made:

The central bank of Nigeria as the regulator of the banking industry should ensure that banks are adequately capitalized to maintain system stability and ensure a level of progress in the industry.

Efficient liquidity is a pronouncement to profitability and solvency which calls for the maintenance of the required ratios as would periodically be demanded by the apex banks.

Bank managers should be aware of the dangers imminent from holding excess cash or lack of cash and avoid any of this. Excess cash should be invested in short term instrument to earn and shore up profit for the stakeholders while a watchful eye should be kept to discern when the cash level falls below the required so as to avoid customers' ill-will and a consequent bank run that can lead to a technical insolvency. Essentially, deposit money banks in Nigeria are required to strike a balance between liquidity and profitability for system stability to hold.

\section{REFERENCES}

1. Abdullah, M. N., \& Jahan, N. (2014). The impact of liquidity on profitability in banking sector of Bangladesh: a case of Chittagong stock exchange. International journal of Economic and business review, 2(10), 17-22.

2. Adebayo, O. Adeyani O. and Olabode, O. (2011): Liquidity Management and Commercial Banks Profitability in Nigeria. Research Journal of Finance and Accounting 2(7/8), 24. 
3. Akinwumi et al (2017). Liquidity Management and Bank Performance in Nigeria. Issues in Business Management and Economics, 5 (6) 88-98

4. Akinwumi I.A., Essien, J.M., \& Adeegboyega, R., (2017). Liquidity Management and Bank

Performance in Nigeria. Issues in Business Management and Economics, 5(6) 88-98.

5. Alshatti, A. S. (2015). The effect of credit risk management on financial performance of the Jordanian commercial banks. Investment Management and Financial Innovations, 12(1), $338-345$

6. Amengor, E. C. (2010). Importance of liquidity and capital adequacy to commercial banks. A Paper Presented at Induction Ceremony of ACCE, UCC Campus.

7. Ariffin, N. M. (2012), Liquidity risk management and financial performance in Malaysia:

8. Bagyenda J, Brownbridge M, Kasekende L (2011). Basel III and the global reform of financial regulation: how should Africa respond? A regulator's perspective. New Rules for Global Finance. Washington D.C.

9. Basel Committee on Banking Supervision (2008), "Principles for Sound Liquidity Risk

10. Bassey, G. E., \& Moses, C. E. (2015). Bank profitability and liquidity management: A case of selected Nigerian deposit money banks. International Journal of Economics, Commerce and Management, 3(4), 1-24.

11. Bhattacharyya, I., \& Sahoo, S. (2011). Comparative Statistics of Central Bank liquidity Management Management. Economic Research International Journal, 11(20), 39-45.

12. Bhunia, A., \& Khan, I. U. (2011). Liquidity management efficiencycase study of Cadbury, Nestle and Federal Inland Revenue Service. Proceedings of the 32ndInternational Business Information Management Association Conference (pp. 7483-7398).

13. Charmler, R., Musah, A., Akomeah, E., \& Gakpetor, E. (2018). The Impact of Liquidity on Performance of Commercial Banks in Ghana. Academic Journal of Economic Studies, 4(4), 7890. Commercial Banks in Malaysia. European Journal of Economics, Finance and Administrative Sciences, 23(1), 149-160.

14. Daniel, B. E. (2017). Liquidity management and performance of deposit money banks in Nigeria

15. Devinaga, R., \& Tan, T. M. (2010). Theoretical Framework of Profitability as Applied to empirical evidence from Islamic banks, Aceh International Journal of Social Sciences 1(2): 68

16. Flannery MJ, Regan P (2008). What Caused the Bank Capital Build-up of the 1990s? Review of Finance 12.

17. Gomez, C. (2008). Financial markets, institutions and services. New Delhi, India: Prentice Hall.

18. Ibe, S.O. (2013). The Impact of Liquidity Management on the Profitability of Banks in
Nigeria. Journal of Finance and Bank Management, 1(1), 37-48.

19. Khan, R. A., \& Ali, M. (2016). Impact of Liquidity on Profitability of Commercial Banks in Pakistan: An Analysis on Banking Sector in Pakistan. Global Journal of Management and Business Research, 16(1)

20. Koranteng, E. (2016). Determinants of liquidity of banks listed on the Ghana Stock Exchange (Doctoral dissertation)

21. Kosmidou, K. (2008). The determinants of banks' profits in Greece during the period of EU financial integration. Managerial Finance, 34(3), 146-159.

22. Kuznetsov, P., \& Muravyev, A. (2001). Ownership concentration and firm performance in Russia: the case of blue chips of the stock market. Acta Oeconomica, 51(4), 469-488.

23. Lartey, V. C., Antwi, S., \& Boadi, E. K. (2013). The relationship between liquidity and profitability of listed banks in Ghana. International Journal of Business and Social Science, 4(3).

24. Liu H, Wilson JO (2010). The profitability of banks in Japan. Applied Financial Economics 20(24). 1851-1866.

25. Marozva, G. (2015). Liquidity and bank performance. The International Business \& Economics Research Journal (Online), 14(3), 453.

26. Musah, A. (2017). The Impact of Capital Structure on Profitability of Commercial Banks in Ghana. Asian Journal of Economic Modelling, 6(1), 21-36.

27. Musah, A., Anokye, F. K., \& Gakpetor, E. D. The Impact of Interest Rate Spread On Bank Profitability In Ghana. European Journal of Business, Economics and Accountancy, 6(1), 27-39.

28. Naceur, S. B.; Kandil, M. (2009), The impact of capital requirements on banks' cost of of Indian Steel Companies (a Case Study). Far East Journal of Psychology and Business, 3(3), 313.

29. Ogonna, O.S.; Ikechukwu, N. C. N. (2016), Effects of Liquidity Management on the Performance of Deposit Money Banks in Nigeria. Journal of Policy and Development Studies, 10(3), 156-169.

30. Olagunju, A., David, A. O., \& Samuel, O. O. (2012). Liquidity management and commercial banks' profitability in Nigeria. Research Journal of Finance and Accounting, 2(7-8), 24- 38.

31. Olatunde, S. (2015). Basel II and Financial Performance of Deposit Money Banks in Nigeria

32. Onoh, J.K. (2002). Dynamics of Money. Banking and Finance in Nigeria: An emerging market, Aba Astra Meridian Publishers.

33. Otekunrin A.O., Fagboro G.D., Nwanji T.I., Asamu F.F., Ajiboye B.O., \& Falaye A.J. (2019). Performance of deposit money banks and liquidity management in Nigeria. Banks and Bank Systems, 14(3), 152-161.

34. Otekunrin, A. O., Nwanji, T. I., Agba, D. Z., Olowookere, J. K., Fakile, S. A., Lawal, S. 
35. Padachi, K. (2006). Trends in Working Capital Management and Its Impact on Firms'

Performance: An Analysis of Mauritian Small Manufacturing Firms. International Review ofBusiness Research Papers, 2(2), 45-58.

36. Raheman, A., \& Nasr, M. (2007). Working capital management and profitability-case of Pakistani firms. International review of business research papers, 3(1), 279-300.

37. Ramadan, I. Z., Kilani, Q. A., \& Kaddumi, T. A. (2011). Determinants of Bank Profitability: Evidence from Jordan. International Journal of Academic Research, 3(4), 180-191

38. Rasiah, D., \& Ming, T. T. (2010). A Theoretical Review of Improving Self Service Effectiveness Using Customer Feedback at Commercial Banks. European Journal of Economics, Finance and Administrative Sciences, 23(1),149-160.

39. Shekhar, K. C., \& Shekhar, L. (2005). Banking theory and practice (19thed.).New Delhi, India: Kay Kay Printers.

40. Shen, I. L., Docquier, F., \& Rapoport, H. (2010). Remittances and inequality: a dynamic migration model. The Journal of economic inequality, 8(2), 197-220.

41. Vong, L. K. (2005). Loans and Profitability of Banks in Macao. AMCM Quarterly Bulletin, 15,91107.

42. Zikmund, G. W., Babin, B. J., Carr, C. J., \& Griffin, M. (2010). Business Research Methods 8th ed. South-Western: Cengage Learning.

43. Marietta, U. dan Djoko Sampurno. (2013). Analisis Pengaruh, Cash Ratio, Return on Assets, Growth, Firm Size, Debt to Equity Ratio terhadap Dividend Payout Ratio. Diponegoro Journal of Management, 2 (3), 1-11.

44. Affandi, F.; Sunarko, B.; \& Yunanto,A.(2018). The Impact of Cash Ratio, Debt To Equity Ratio, Receivables Turnover, Net Profit Margin, Return On Equity, and Institutional Ownership To Dividend Payout Ratio. Journal of Research in Management, 1(4), 1-11.

45. Sile, N.; OOlweny, T.; \& Sakwa, M. (2019). Liquidity as a Determinant of Commercial Banks Financial Performance in Kenya. International Journal of Economics, Commerce and Management 7(1), 1-11. 